\title{
In vitro culture of bovine egg fertilized either in vivo or in vitro
}

\author{
B. Marquant-Le Guienne ${ }^{1}$, M.Gérard ${ }^{2}$, A. Solari ${ }^{2}$ \\ and $\mathrm{C}$. Thibault ${ }^{*}$ \\ 1 UNCEIA, 13 Rue Jouet, 94200 Maisons-Alfort; \\ 2 INRA, physiologie animale, 78350 Jouy-en-Josas, France
}

(3rd Franco-Czechoslovak Meeting, INRA, Jouy-en-Josas, 13-14 December 1988)

\begin{abstract}
Summary - Three-quarters of in vivo and one-third of in vitro fertilized bovine eggs reached blastocyst stage when cultured on tubal cell monolayers (TCM), but no hatching occurred in B2 medium supplemented with estrous cow serum. When after 3 days of culture on TCM, morulae were transferred on endometrial cell monolayers (UCM), the same proportion of blastocysts was obtained and one-third of them hatched.

Histological studies of hatched blastocysts showed that the number of inner cells was significantly lower than in hatched blastocysts recovered in vivo 8-8.5 days after ovulation. Moreover, the number of pycnotic cells was higher than normal, although mitosis were present. On the contrary, there was no difference in either the number or the appearance of trophoblastic cells between blastocysts obtained in vitro and in vivo. The addition of transforming growth factor (TGF- $\beta$ ) to either TCM or UCM co-cultures at the very beginning of blastocyst formation specifically stimulated growth of the inner cell mass (ICM). The number of cells at hatching was about double (120) and significantly higher than that found in 8-8.5-day blastocysts in vivo. Moreover, hatching percentages were similar to the controls, even when eggs were cultured for 8 days only on TCM. However the proportion of pycnotic cells remained higher than normal, although many mitotic cells were unevenly distributed in ICM) In vivo during hatching, there were always pycnotic cells in ICM, but their number was limited and approximately similar to the number of mitosis. The uterine factors which control both mitosis and pycnosis in ICM remain to be discovered.
\end{abstract}

\section{culture - bovine blastocyst - hatching - TGF- $\beta$}

Résumé - Culture in vitro de l'œut de vache fécondé soit in vitro soit in vivo. Il est possible de contrôler rapidement la réussite de la fécondation in vitro, l'efficacité du transfert de gènes ou celle du clonage, à condition, de cultiver l'ceuf au moins jusqu'au stade blastocyste éclos. Ceci est particulièrement important pour les gros mammifères dont le coût ne permet pas de tester tous les essais par des transferts dans des femelles receveuses. Par ailleurs, chez les bovins, le transfert par voie non chirurgicale ne pouvant se faire avant le 6-7e $j$ après l'ovulation il importe de disposer de blastocystes et non simplement d'œufs aux premiers stades de la fécondation comme chez les primates. Nous avons donc cherché à obtenir par culture des blastocystes pouvant être considérés comme normaux par comparaison avec des blastocystes récupérés in vivo $7 j$ et $8,5 j$ après la fécondation (Bl-7 et Bl-8,5). La culture sur tapis de cellules tubaires de vache (TCM) permet le déve-

\footnotetext{
* Correspondence and reprints.
} 
loppement jusqu'au stade blastocyste expansé mais jamais jusqu'à l'éclosion. A partir d'œufs cultivés $3 j$ sur TCM, puis 4-5 j sur tapis de cellules utérines (UCM), nous avons obtenu respectivement $31 \%$ d'éclosions pour les œufs fécondés in vivo et $37 \%$ pour les œufs fécondés in vitro, en mimant les conditions naturelles; ces valeurs sont significativement inférieures à celle observée in vivo (70\%) dans des délais semblables. De plus, le nombre de cellules du bouton embryonnaire (ICM) de ces blastocystes éclos est significativement plus petit que celui des Bl-8,5 (63 contre 87, Fig. 1a), alors que le nombre de cellules du trophoblaste n'est pas significativement différent (Fig. 1b). Enfin, bien que des mitoses soient régulièrement présentes, le nombre de cellules picnotiques est significativement plus élevé que chez les B1-8,5. Le rôle joué par le TGF- $\beta$ (transforming growth factor- $\beta$ ) dans la différenciation de l'embryon de xénope, nous a conduit à rechercher si la présence de ce facteur de croissance dans le milieu de culture pouvait augmenter le nombre de cellules de I"ICM et réduire le taux de cellules picnotiques. Le TGF- $\beta$ entraine effectivement une augmentation hautement significative du nombre de cellules (120 contre 87). Le nombre de mitoses est également plus élevé, bien que non significativement (Fig. 2a). Malgré cela le nombre de cellules picnotiques demeure significativement plus important que chez les BI-8,5 (Tableaux III et IV). Par ailleurs, la présence de TGF- $\beta$ élève le taux d'éclosion à des valeurs identiques à celle des Bl-8,5 et permet l'éclosion sur TCM sans passage sur UCM et ceci à un taux identique à celui des témoins Bl-8,5. Ainsi TGF- $\beta$ permet d'augmenter spécifiquement le nombre de cellules de l'ICM, même au delà de la valeur normale, alors qu'il est sans effet significatif sur le trophoblaste. De plus, il permet un taux d'éclosion in vitro identique à celui observé in vivo 8,5 jours après la fécondation. La juxtaposition dans I'ICM de mitoses et de cellules pycnotiques mais en nombre plus élevé que dans les $B / 7$ et 8,5 montre que le milieu utérin règle la taille de l'ICM en limitant le nombre de cellules qui dégénèrent, ce que nous n'avons pas réussi à obtenir dans notre système de culture.

culture - blastocyste - vache - éclosion - TGF- $\beta$

\section{INTRODUCTION}

It has been shown that in vivo fertilized ovine and caprine eggs are unable to cleave in culture beyond the 8-12-cell stage (Wintenberger et al., 1954). The same observation has been made on bovine egg (Thibault, 1966). Many attempts to stimulate further cleavage by enriching classical culture media with ovine, bovine, equine or fetal calf blood serum have been unsuccessful. A discovery by Gandolfi \& Moor (1987) showed that the 8-cell stage block did not occur if sheep in vivo fertilized eggs were cultured on epithelial tubal cell monolayers, or even on fibroblasts. After such co-cultures, morulae and blastocysts were obtained and lambs were born from transferred blastocysts. This procedure has been extended to bovine egg (see Rexroad, 1989). Granulosa cells also seem able to support complete devel- opment (Goto et al., 1988). However, the percentage of eggs reaching the blastocyst stage is low (15\%, Goto et al., 1988). The same conclusion can be inferred from the fact that, in many papers, morulae and blastocysts are presented together. In cattle, non-surgical embryo transfer by the cervical route cannot be performed before day 6 or 7 . At this time the embryo has reached the blastocyst stage. Thus in view of practical application, in vitro fertilized eggs must be cultured beyond the morula stage. An adequate culture system may also offer the possibility to check the presence and possibly the early expression of genes tranferred at one-cell stage and the efficacy of cloning procedures, thereby avoiding expensive transfer to recipient females. It was the purpose of this study to obtain normal hatched blastocysts in culture from in vivo or in vitro fertilized bovine eggs. 


\section{MATERIAL AND METHODS}

Cow and heifers of Friesian or Charolais breed were synchronized according to Eldsen et al. (1978) by "Estrumate" (Coopers, France) and superovulated by a partially purified pFSH preparation containing $\approx 10 \%$ of $\mathrm{LH}$. Final follicular maturation and ovulation were synchronized by injection of the equivalent of $2 \mathrm{mg}$ of pure $\mathrm{pLH}$ at the beginning of estrus. These hormones were prepared and generously supplied by Combarnous (INRA, CNRS). Samples of frozen semen from the same bull were used for in vivo and in vitro inseminations.

Oocytes used in in vitro fertilization were recovered $24-26 \mathrm{~h}$ after $\mathrm{LH}$ injection by puncture of the largest follicles. Delay between slaughter and puncture was 15-30 min. Oocytes encompassed in expanded cumulus were cultured in B2 medium (INRA, Ménézo) $+10 \%$ of estrus cow serum (ECS) for 4-6 h before in vitro insemination. In vivo fertilized eggs were recovered either a few hours after ovulation or $24 \mathrm{~h}$ later by flushing the tubes with PBS within 30 min after slaughter. The eggs were rapidly transferred to the selected medium. All manipulations were performed in sterile rooms maintained at $32-35{ }^{\circ} \mathrm{C}$ and at $80-90 \%$ humidity.

In vitro fertilization procedure has been described by Marquant-Le Guienne et al. (1989). In vitro fertilized eggs were freed of corona cells and attached sperms $18 \mathrm{~h}$ after insemination in B2 medium supplemented with $10 \%$ ECS and then transferred to tubal cell monolayers. In vivo fertilized eggs recovered either a few hours after fertilization or $30 \mathrm{~h}$ later were cultured under the same conditions.

Blastocysts were recovered in vivo by the cervical route 7 or 8.5 days after ovulation according to Ozil et al. (1980). Ovulation has been estimated to occur $30 \mathrm{~h}$ after the onset of estrus (Thibault, 1967).

Tubal cell monolayers were prepared as follows : $1 \mathrm{ml}$ of $\mathrm{HBSS}$ (without $\mathrm{Ca}^{2+}$ and $\mathrm{Mg}^{2+}$ ) containing $0,46 \mathrm{mg}$ of trypsin (activity $3.6 \mathrm{U} / \mathrm{mg}$, SERVA) $+1.4 \mathrm{mg}$ of collagenase $(0.7-0.8 \mathrm{U} /$ $\mathrm{mg}$, SERVA)) was infused into the lumen of each tube ligated at both ends. Thirty min later, the content was flushed with $1 \mathrm{ml}$ of cow or calf serum and centrifuged for $15 \mathrm{~min}$ at $300 \mathrm{~g}$. The supernatant was discarded and small pieces of tubal epithelium were gently resuspended in 0,5 $\mathrm{ml}$ of B2 medium supplemented with $10 \%$ of ECS. Generally $100 \mu \mathrm{l}$ of this suspension was distributed in Nunc or Falcon plates, each well containing $350 \mu \mathrm{l}$ of the same medium. Nonadhering cells or debris were removed $24 \mathrm{~h}$ later and the medium was renewed every 2 or 3 days.

Uterine cell monolayers were also prepared from cows slaughtered for oocytes or fertilized egg collection on day 0 or day 1 . This is not the optimal time during the estrus cycle for uterine cell viability (Fortier et al., 1988) and plating occurred irregularly. Therefore two techniques were used simultaneously. After ligation of both ends of the uterine horn, $10 \mathrm{ml}$ of HBSS + trypsin and collagenase were infused into the horn through the myometrium in sterile conditions. One hour later, HBSS was removed by aspiration and the horn was opened. Small pieces of tissue were obtained by gently scraping the epithelium. Cow or calf serum was then added to stop proteolytic activity. The biggest fragments were removed and the suspension was centrifuged as described for tubal cell preparation. The second uterine horn was opened and shreds of epithelium were removed, put in HBSS + enzymes (trypsin + collagenase or collagenase alone) and shaken for $10-15 \mathrm{~min}$. Cow or calf serum was added and the procedure was carried out as previously mentioned. All manipulations were performed at $25-27^{\circ} \mathrm{C}$ in sterile conditions. As uterine cells adhere slowly, non-adhering cells and debris were completely removed after $48 \mathrm{~h}$ or even $72 \mathrm{~h}$. After 3 days of culture, B2 + ECS was replaced by B2 + blood serum of day 6 cow (D6 CS). No care was taken to isolate the epithelial and stromal cells since it has been shown that stromal cells are absolutely necessary to the formation of progesterone receptors in epithelial cells in response to estradiol (Inaba et al., 1988). The two-type cell ratio did not change whatever the culture time.

Under our culture conditions (B2 medium + cow serum, under air $+5 \% \mathrm{CO}_{2}, \mathrm{pH} 7.4$ ), the tubal and uterine cells, after covering the bottom of the wells, stopped dividing and remained able to support blastocyst formation for many weeks and sometimes many months. Therefore we only used primary cultures.

In some experiments, transforming growth factor $\beta$ (TGF- $\beta$ ), (BTI, MA, USA) was added at 
a concentration of $0.3 \mathrm{ng} / \mathrm{ml}$ to the culture at the early beginning of the formation of blastocoele cavity; thereafter $0.1 \mathrm{ng} / \mathrm{ml}$ was added every day up to the day of fixation.

Eggs, morulae and blastocysts were fixed in ethanol-acetic acid $(3 / 1)$ for $1-2$ days, then post-fixed in Bouin Hollande fixative for $24 \mathrm{~h}$, double-embedded in Agar-paraffin, cut into serial sections $15 \mu \mathrm{m}$ thick, and stained with hematoxylin-eosin. The nuclear state (normal, pycnotic, interphasic or mitotic was assessed and the number of cells determined by microscopical examination $(480 \mathrm{x})$. The nuclei of the inner cell mass (ICM) were small and round, whereas those of trophoblast were flat and bigger. This criterion was used to determine the number of cells of trophoblast and ICM. The Fisher exact test was used in studies on hatching rates. Comparisons of the numbers of cells, numbers of mitotic and pycnotic cells between each experimental group and their controls were carried out by the two sample $t$-tests when variances were equal or by Satterthwhite's approximation when variances were unequal (SAS/Stat Guide, 1987). Absolute numbers of mitoses and pycnoses were analyzed after square root transformation ( $V$ number +0.5 ) (Steel and Torrie, 1980).

\section{RESULTS}

When in vivo or in vitro fertilized eggs were cultured in B2 medium supplemented by fetal calf serum, a high proportion of eggs cleaved regularly (Table I) but none of them cleaved beyond the 8-12-cell stage. When in vivo or in vitro fertilized eggs were cultured on tubal cell monolayer, they cleaved regularly and $73 \%$ of the morulae formed blastocysts (Table II). About fifty percent of them were expanded after 8 days of culture, but none of them hatched (even after 11 days).

As it is known that in non-primate mammals, fertilized eggs experimentally maintained in the tubes degenerate at blastocyst stage, we tried to mimic the natural in vivo situation by transferring morulae on uterine cell monolayers (UCM) after 3 days of culture on tubal cell monolayers (TCM). In these conditions, $68 \%$ of the morula developed to blastocysts, and $\approx 8$ days after fertilization $31 \%$ of these blastocysts hatched (Table II). When in vitro fertilized eggs were cultured under the same condi-

Table I. In vitro fertilization and cleavage of bovine oocytes matured either in vitro or in vivo.

\begin{tabular}{|c|c|c|c|c|c|}
\hline Oocyte maturation & $\begin{array}{l}\text { Fertilization } \\
\text { No. }\end{array}$ & $\%$ & $\begin{array}{l}\text { Cleavage } \\
\text { No. }\end{array}$ & $\%$ & $\begin{array}{c}>8-12 \text { cells } \\
\text { after } 96 \mathrm{~h} \\
\text { in } B 2+F C S^{*}\end{array}$ \\
\hline $\begin{array}{l}\text { In vitro } 26-30 \mathrm{~h} \\
\mathrm{~B} 2+\mathrm{ECS}{ }^{* *} \text { and } \\
\text { granulosa cells }\end{array}$ & $100 / 128$ & 78 & $64 / 74^{\star \star \star}$ & 86 & not studied \\
\hline $\begin{array}{l}\text { In vivo } 24 \mathrm{~h} \\
+ \text { in vitro } 4-6 \mathrm{~h}\end{array}$ & $28 / 34$ & 82 & $27 / 28$ & 96 & $0 / 27$ \\
\hline
\end{tabular}

${ }^{*} B 2+$ FCS : B2 medium + fetal calf serum.

** B2 + ECS : B2 medium + estrus cow serum.

*** some fertilized eggs have been fixed. 
Table II. Culture of in vivo or in vitro fertilized bovine eggs on tubal cell monolayers (TCM) or TCM and uterine cell monolayers (UCM) with or without transforming growth factor $\beta$ (TGF- $\beta$ )

\begin{tabular}{|c|c|c|c|c|c|}
\hline \multirow[t]{2}{*}{$\begin{array}{l}\text { Culture } \\
\text { systems }\end{array}$} & \multirow[t]{2}{*}{$\begin{array}{l}\text { Duration } \\
\text { in days }\end{array}$} & \multicolumn{2}{|c|}{$\begin{array}{l}\text { Blastocyst } \\
\text { morula }\end{array}$} & \multicolumn{2}{|c|}{$\begin{array}{c}\text { Hatched } \\
\text { blastocyst }\end{array}$} \\
\hline & & No. & $\%$ & No. & $\%$ \\
\hline $\operatorname{TCM}(1)$ & $\geq 8 \mathrm{~d}$ & $25 / 34$ & 73 & $0 / 25$ & $0 \mathrm{a}$ \\
\hline $\begin{array}{l}\text { TCM + UCM (1) } \\
\text { TCM + UCM (2) }\end{array}$ & $\begin{array}{r}>7 d \\
8 d\end{array}$ & $\begin{array}{l}54 / 89 \\
10 / 30\end{array}$ & $\begin{array}{l}68 \\
33\end{array}$ & $\begin{array}{c}16 / 51 \\
3 / 8\end{array}$ & $\begin{array}{l}31 b^{1} \\
37 b^{2}\end{array}$ \\
\hline $\begin{array}{l}\operatorname{TCM}(1) \\
+\operatorname{TGF}-\beta(2 d)\end{array}$ & $8 d$ & $8 / 15$ & 53 & $7 / 8$ & $87 c$ \\
\hline $\begin{array}{l}\text { TCM + UCM (1) } \\
+ \text { TGF-B (2d) }\end{array}$ & $\geq 7.5 \mathrm{~d}$ & $16 / 17$ & 94 & $10 / 16$ & $62 d$ \\
\hline In vivo blastocysts & 8.5 day & & & $7 / 10$ & $70 \mathrm{e}$ \\
\hline
\end{tabular}

(1) Fertilization in vivo; (2) fertilization in vitro.

$\mathrm{b}^{1}, \mathrm{~b}^{2}$ vs e, $P<0.03$; $\mathrm{b}^{1}$ vs d, $P<0.04$; a vs $\mathrm{c}, P<0.01$.

tions, a lower proportion of morulae reached the blastocyst stage (33\%) but a similar percentage of hatching was observed $(37 \%$, Table II). Thus the passage of morulae from TCM to UCM allowed hatching. Hatching followed a time schedule similar to that in vivo 8-8.5 days after fertilization (Table III). However, histological studies showed that in vitro hatched blastocysts had a significantly lower number of cells in ICM than those found in in vivo hatched blastocysts $(P<0.02, \mathrm{Fig}$. 1a and Table IV). Moroever, the average number of pycnotic cells in ICM was much higher $(P<0.01)$, although mitoses were present in ICM as well as in the trophoblast (Tables III and IV).

The relatively low number of cells in ICM and the simultaneous presence of mitotic and degenerating cells suggests that our culture conditions did not provide any factors which could control the growth and differentiation of ICM, whereas the tropho- blast remained in every case perfectly healthy. This hypothesis has been tested by adding to the culture medium transforming growth factor $\beta$ (TGF- $\beta$ ) which is known to play a key role in the early differentiation of Xenopus embryo (Kimelman \& Kirschner, 1987; Weeks \& Melton, 1987; Harland, 1988). TGF- $\beta$ was added to the culture medium of both tubal and uterine cells when the most advanced morulae were reaching the very early blastocyst stage. Thus in vivo fertilized eggs either remained on tubal cells for 8 days (TGF- $\beta$ being present during the last 2 days) or were transferred to uterine cells at day 4 (TGF- $\beta$ being added during the last 2 or 3 days of culture). TGF- $\beta$ significantly enhanced the hatching rate of TCM-UCM embryos (62 vs 31; $P<0.04$, Table II). Moreover, hatching occurred when the eggs remained on TCM ( $87 \%$ vs $0 \%$; $P<0.01$, Table II). In these in vitro systems hatching occurred as in vivo, i.e. $\approx 8$ days after fertilization. 
Table III. Histological studies of bovine blastocysts collected in vivo 7 or 8.5 days after fertilization.

\begin{tabular}{|c|c|c|c|c|c|c|}
\hline \multirow[t]{2}{*}{ Blastocyst } & \multirow{2}{*}{$\begin{array}{c}\text { Total } \\
\text { No. cells }\end{array}$} & \multirow{2}{*}{$\begin{array}{l}\text { Trophoblast } \\
\text { No. cells }\end{array}$} & \multirow{2}{*}{$\begin{array}{c}I C M \\
\text { No. cells }\end{array}$} & \multirow{2}{*}{$\begin{array}{c}\text { Ratio } \\
\text { ICM/total }\end{array}$} & \multicolumn{2}{|c|}{ Inner cell mass } \\
\hline & & & & & mitosis & pycnosis \\
\hline $\begin{array}{l}\text { 7-day old } \\
\text { expanded }(14)^{\star \star}\end{array}$ & $\begin{array}{c}216 \\
173-255\end{array}$ & $\begin{array}{c}134 \\
102-184\end{array}$ & $\begin{array}{c}82 \\
55-110\end{array}$ & 0.38 & $\begin{array}{c}6 \\
1-14\end{array}$ & $\begin{array}{c}5 \\
1-14\end{array}$ \\
\hline $\begin{array}{l}\text { 8.5-day old } \\
\text { expanded (3) }\end{array}$ & $\begin{array}{c}288 \\
272-304\end{array}$ & $\begin{array}{c}201 \\
186-222\end{array}$ & $\begin{array}{c}87 \\
82-93\end{array}$ & 0.30 & $\begin{array}{c}2 \\
1-3\end{array}$ & 0 \\
\hline $\begin{array}{l}\text { 8.5-day old } \\
\text { hatched (7) }\end{array}$ & $\begin{array}{c}251 \\
197-309\end{array}$ & $\begin{array}{c}164 \\
134-213\end{array}$ & $\begin{array}{c}87 \\
62-100\end{array}$ & 0.35 & $\begin{array}{c}4 \\
2-7\end{array}$ & $\begin{array}{c}3 \\
0-8\end{array}$ \\
\hline
\end{tabular}

- Fertilization has been estimated to occur $30 \mathrm{~h}$ after the onset of estrus (Thibault, 1967).

** (...) Number of blastocysts studied.

Table IV. Comparison of cell number and cell quality of hatched blastocysts obtained after \# 8 days of culture in different conditions.

\begin{tabular}{|c|c|c|c|c|c|c|}
\hline \multirow[t]{2}{*}{ Culture system } & \multicolumn{3}{|c|}{ Cell No. } & \multirow{2}{*}{$\begin{array}{l}\text { Ratio } \\
\text { ICM/Total }\end{array}$} & \multicolumn{2}{|c|}{$I C M$} \\
\hline & Total & trophoblast & $I C M$ & & mitosis & pycnosis \\
\hline $\begin{array}{l}\text { TCM-UCM } \\
\text { (1) }\end{array}$ & $\begin{array}{c}197 \\
(121-316)\end{array}$ & $\begin{array}{c}134 \\
(76-223)\end{array}$ & $\begin{array}{c}63 \\
(24-110)\end{array}$ & 0.32 & $(0-16)$ & $\begin{array}{c}17 a \\
(0-46)\end{array}$ \\
\hline $\begin{array}{l}\text { TCM-UCM } \\
\text { (2) }\end{array}$ & $\begin{array}{l}200 \\
(189-220)\end{array}$ & $\begin{array}{c}139 \\
(131-153)\end{array}$ & $\begin{array}{c}61 \\
(57-67)\end{array}$ & 0.31 & $\begin{array}{l}7 \\
(5-8)\end{array}$ & $\begin{array}{l}5 \\
(3-6)\end{array}$ \\
\hline $\begin{array}{l}\text { TCM + TGF- } \beta \\
\text { (1) }\end{array}$ & $\begin{array}{c}256 \\
(230-284)\end{array}$ & $\begin{array}{c}139 \\
(115-176)\end{array}$ & $\begin{array}{c}118 \\
(102-137)\end{array}$ & 0.46 & $\begin{array}{c}5 \\
(3-7)\end{array}$ & $\begin{array}{l}39 a \\
(23-57)\end{array}$ \\
\hline $\begin{array}{l}T C M-U C M+T G F-\beta \\
\text { (1) }\end{array}$ & $\begin{array}{l}300 \\
(214-411)\end{array}$ & $\begin{array}{c}191 \\
(122-263)\end{array}$ & $\begin{array}{c}120 \\
(60-162)\end{array}$ & 0.38 & $\stackrel{8}{(0-17)}$ & $\begin{array}{l}32 a \\
(9-54)\end{array}$ \\
\hline
\end{tabular}

(1) In vivo fertilization; (2) in vitro fertilization; (...) range.

a : significantly higher than in vivo control $(P<0.01$, Table $\mid \mathrm{II})$.

Number of embryos studied are given in Figure 1. 
Were these blastocysts similar to those recovered in vivo from superovulated cows 8-8.5 days after fertilization?

When blastocysts were cultured on TCMUCM plus TGF- $\beta$ the numbers of cells in ICM were significantly higher $(P<0.01)$ than in blastocysts cultured without this factor (Fig. 1a, Tables III and IV). In hatched blastocysts obtained when TGF- $\beta$ was added to TCM culture, the numbers of cells in ICM were significantly higher than in in vivo controls $(P<0.01$, Tables III and IV, Fig. 1a). No comparison could be made with blastocysts obtained on TCM alone since no hatching was observed in that situation. These results indicate that TGF- $\beta$ always stimulated mitotic activity. However, the numbers of pycnotic cells in ICM remained significantly higher than in in vivo controls $(P<0.01$; Tables III and IV).

When comparing the numbers of mitotic and pycnotic cells in ICMs of in vitro produced blastocysts (Fig. 2a, 2b) it is evident first that very few of them were in the range values of in vivo hatched blastocysts; and second, that in vitro there was a great variation in histological parameters from one blastocyst to the other. These ob- servations indicate that very few blastocysts produced in vitro would be able to develop up to term.

As shown in Table III, the growth of ICM in vivo between day 7 and day 8.5 was limited ( 87 cells vs 82 cells) and lower than in trophoblast $(6 \%$ vs $22 \%$ ). A few mitoses were always observed (2 to 7 ), but pycnotic cells were also present ( 0 to 8 , Table III).

A differential rate of growth between trophoblast and ICM during expansion and hatching seemed to occur in vivo; the ratios between ICM and total cell number were respectively 0.38 and 0.35 in blastocysts recovered in the uterus at day 7 and day 8.5 (Table III). The ratios of hatched blastocysts obtained in vitro were different; they were lower in TCM-UCM-hatched blastocysts (0.32) and higher in the two TGF- $\beta$ groups (0.46 and 0.40 ) (Table IV). As in all the experimental groups, the numbers of trophoblastic cells did not differ significantly from the control (Fig. 1b), the ratio differences between in vivo and in vitro blastocysts mainly depended on ICM development (compare Table III and IV). Thus the low ratio $(0.32)$ in TCM-UCM hatched blastocyst was due to an underdevelopment of ICM and the high ratios,
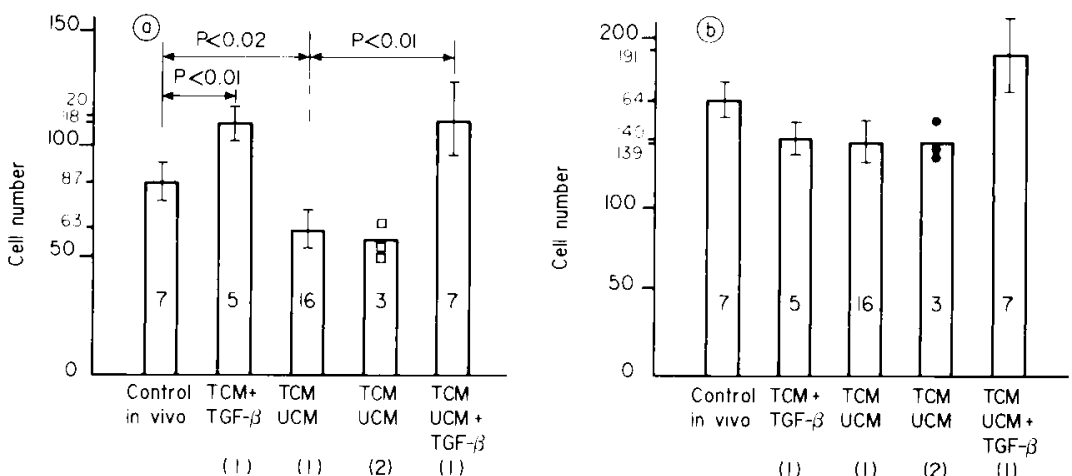

Fig. 1. Number of cells in inner cell mass (a) and in trophoblast (b). Number of embryos are indicated in the columns. Control = blastocysts flushed 8.5 days after fertilization; TCM = lubal cell monolayer; $\mathrm{UCM}=$ uterine cell monolayer. TCM-UCM = eggs were cultured 3 days on TCM then on UCM. (1) In vivo fertilized eggs; (2) in vitro fertilized eggs. 


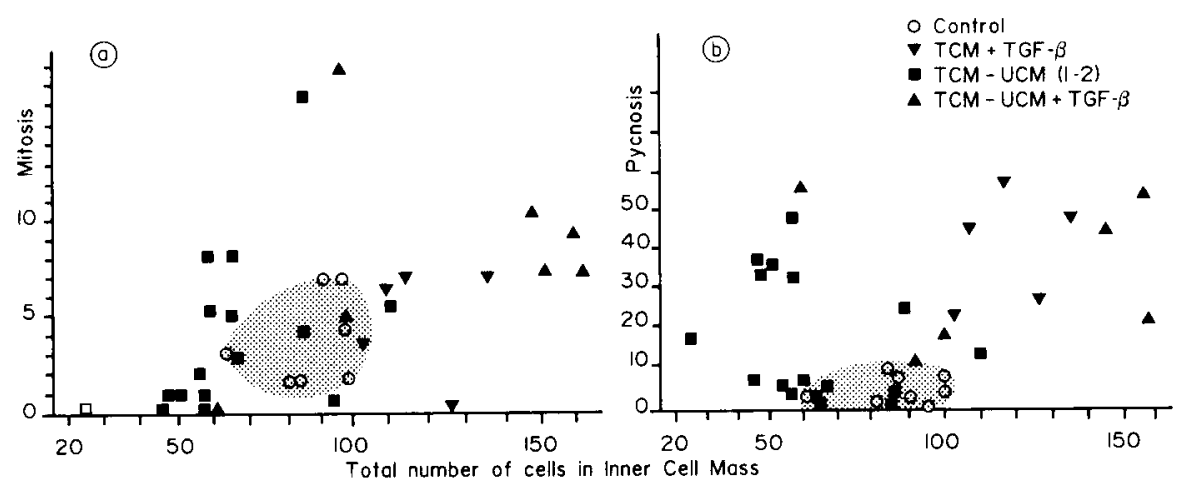

Fig. 2. Number of mitotic cells (a) and pycnotic cells (b) in inner cell mass of in vivo and in vitro hatched blastocysts. In X-axis are the number of cells in ICM. Numbers from in vivo blastocysts are included in shaded area.

when TGF- $\beta$ was present, resulted from a dramatic increase of cell multiplication only in ICM.

\section{DISCUSSION}

The culture of bovine fertilized eggs on tubal cell monolayers in $\mathrm{B} 2$ medium supplemented with estrus cow serum allowed a high rate of blastocyst formation. However, no hatching occurred although the total number of cells was in the range of in vivo hatched blastocysts (172-262 vs 173255; data not shown). On the contrary, when cultured on uterine cell monolayers after 3-day culture on TCM, one-third of the blastocysts hatched, although the number of cells of the whole blastocysts and of ICMs as well as their ratios were lower than in in vivo controls. There is no similar information on any species in the literature. Kajihara et al. (1988) have only given the total number of cells in hatching + hatched bovine blastocysts obtained after 8 to 12 days of culture on granulosa cells of in vi- tro fertilized eggs. Moroever, the average number of cells was surprisingly low (mean $=128$, range $22(?)-250)$ for this stage of development.

A differential rate of growth between trophoblast and ICM during expansion and hatching has been already mentioned by Papaionnaou \& Ebert (1988) in pig embryo, the ratio between ICM and total cell number decreasing after hatching from 0.24 to 0.15 .

TGF- $\beta$ has a wide range of effects (see Rizzino, 1988). On cell growth TGF- $\beta$ seemed to potentiate or suppress the growth-stimulatory activity of other growth factors. Mesoderm differentiation of Xenopus embryo depends on a synergistic action of TGF- $\beta$ and fibroblast growth factor (FGF) (Kimelman \& Kirschner, 1987). In mammals, it has been recently reported that mouse blastocyst cultured in vitro produces a growth factor which is immunologically related to FGF (Rizzino, 1988) but the presence of TGF- $\beta$ in this species has been only studied in later stages of development (Heine et al., 1987). Nothing is known in other mammals. 
In our experiments, it is clear that TGF$\beta$ mainly stimulated mitotic activity in ICM. This effect might be indirect, via a stimulation of other growth factors from tubal and uterine cells. Whatever the mitogenic growth factor involved, this response seems to indicate that growth factor receptors are present in ICM. In vivo during the hatching period, the uterine milieu probably stimulates the multiplication of inner cells by growth factors and simultaneously dampers ICM development by allowing a limited rate of pycnosis. This double mechanism is evidenced in mouse blastocysts during delayed implantation; in this situation, the number of inner cells does not increase, or even decreases, although DNA synthesis is maintained in ICM for at least a few days (Given, 1988). Unfortunately uterine factors involved in the arrest of blastocyst development in delayed implantation have not been identified yet. In our culture system we could not stimulate the multiplication of inner cells and simultaneously limit the number of pycnotic cells to a normal rate. We can speculate that our system could not support metabolic exchanges in ICM or could not provide specific uterine factors, for instance from endometrial glands. These hypotheses are now under investigation.

It is generally assumed that TGF- $\beta$ plays a role in cell differentiation via its effects on the extracellular matrix; however, in our experiments we only observed a mitogenic effect and endoderm differentiation was not enhanced.

\section{ACKNOWLEDGMENTS}

We would like to thank P. Cochaud, B. Moret and the farm staff of Bressonvilliers and Jouyen-Josas for assistance with the management of animals.

\section{REFERENCES}

Eldsen R.P., Nelson L.D. \& Seidel J.R. (1978) Superovulating cows with FSH and PMSG. Theriogenology 9, 17-26

Fortier M.A., Guilbault L.A. \& Grasso F. (1988) Specific properties of epithelial and stromal cells from the endometrium of cows. J. Reprod. Fertil. 83, 239-248

Gandolfi F. \& Moor R.M. (1987) Stimulation of early embryonic development in the sheep by co-culture with oviduct epithelial celis. $J$. $R \theta$ prod. Fertil. 81, 23-28

Given R.L. (1988) DNA synthesis in the mouse blastocyst during the beginning of delayed implantation. J. Exp. Zool. 248, 265-370

Goto K., Kajihara Y., Kosalka S., Koba M., Nakanishi Y. \& Ogawa K. (1988) Pregnancies after co-culture of cumulus cells with bovine embryos derived from in vitro fertilization of in vitro matured follicular oocytes. J. Reprod. Fertil. 83, 753-758

Harland R. (1988) Growth factors and mesoderm induction. Trends Genet. 4, 62-63

Heine U.I., Munoz E.F., Flanders K.C., Ellingsworth L.R., Lam H.-Y.P., Thompson N.L., Roberts A.B. \& Sporn N.B. (1987) Role of transforming growth factor $\beta$ in the development of the mouse embryo. J. Cell. Biol. 105, 2861-2876

Inaba T., Wiest W.G., Strickler R.C. \& Mori J. (1988) Augmentation of the response of mouse uterine epithelial cells to estradiol by uterine stroma. Endocrinology 123, 1253-1258

Kajihara Y., Goto K., Tokumara M., Koba M., Nakanishi Y. \& Ogawa K. (1988) Number of blastomeres and chromosome abnormalities of bovine blastocysts obtained from in vitro matured, fertilized and cultured oocytes. Jpn J. Anim. Reprod. 34, 191-198

Kimelman D. \& Kirschner M. (1987) Synergistic induction of mesoderm by FGF and TGF- $\beta$ and the identification of an mRNA coding for FGF in the early Xenopus embryo. Cell 51, 869-877

Marquant-Le Guienne B., Humblot M., Thibier M. \& Thibault C. (1989) In vitro fertilization of in vitro matured bovine oocytes. Application to the prediction of the fertilizing ability of bulls. Reprod. Nutr. Develop. (submitted)

Ozil J.P., Heyman Y. \& Cassou R. (1980) Embryo recovery in young heifers and large donors 
cows. 9th Int. Congr. Anim. Reprod. Artif. Insem. 5, 581-584

Papaionnaou V.E. \& Ebert K.M. (1988) The preimplantation pig embryo : cell number and allocation to trophectoderm and inner cell mass of the blastocyst in vivo and in vitro. Development 102, 793-803

Rexroad C.E. (1989) Co-culture of domestic animal embryos. Theriogenology 31, 105-114

Rizzino A. (1988) Transforming growth factor- $\beta$ : multiple effects on cell differentiation and extracellular matrices. Develop. Biol. 130, 411-422

Steel R.G.D. \& Torrie J.H. (1980) Principles and Procedures of Statistics. A Biometrical Approach. MacGraw Hill, NY, pp. 663
Thibault C. (1966) La culture in vitro de l'œuf de vache. Ann. Biol. Anim. Biochim. Biophys. 6, 159-164

Thibault C. (1967) Analyse comparée de la fécondation et de ses anomalies chez la brebis, la vache et la lapine. Ann. Biol. Anim. Biochim. Biophys. 7, 5-23

Weeks D.L. \& Melton D.A. (1987) A maternal mRNA localized to the vegetal hemisphere in Xenopus eggs codes for a growth factor related to TGF- $\beta$. Cell 51, 861-867

Wintenberger S., Dauzier L. \& Thibault C. (1953) Le développement in vitro de l'œuf de la brebis et de la chèvre. CR Soc. Biol. 147, 19711973 